\title{
WAREHOUSE AND LOGISTICS CENTRES IN POLAND
}

\section{TADEUSZ BOCHEŃSKI}

University of Szczecin, Faculty of Geosciences, POLAND

e-mail: tadeusz.bochenski@usz.edu.pl

RECEIVED
ACCEPTED
JEL
CLASSIFICATION

KEYWORDS

ABSTRACT
10 December 2018

28 December 2018

R33, R49

logistic centre, warehouse centre, warehouse stock, Poland

This article analyses the distribution and development of selected logistical infrastructure facilities in Poland. The distribution of warehouse and logistics centres as well as the development of the modern warehouse space market were examined. The article presents the number of facilities and their warehouse area in 2012 and 2017. Furthermore, concentration areas of this type of infrastructure and companies that manage them were indicated, as well as potential logistics centres were characterized. The differences between a warehouse and a logistics centre were presented. The analysis was based on the Cushman \& Wakefield's offer and information published by logistics centre operators and port authorities. In 2018, there were approximately 200 warehouse centres in Poland with a total warehouse area of over 15 million $\mathrm{m}^{2}$ and only 2 logistics centres: Silesian Logistics Centre in Gliwice and CLIP Logistics in Swarzędz. The biggest industrial developers that offered warehouse area to let in 2017 were: Prologis, Logicor, Segro and Panattoni. Most of the warehouse centres provided services using exclusively road transport.

\section{Introduction}

The aim of this article is to analyse the distribution and development of selected logistical infrastructure facilities in Poland. The location of warehouse and logistics centres, as well as the development of the modern warehouse space market were examined. These facilities constitute important elements of logistical infrastructure. Concentration areas of this type of infrastructure and companies managing them were indicated, as well as potential 
logistics centres were characterized. Moreover, the differences between a warehouse and a logistics centre were presented. Attention was put on the access of such facilities to various modes of transport (multimodality).

The data regarding warehouse centres presented in the article were obtained from Cushman \& Wakefield's offer. The company is one of the world's largest consultancy and intermediary companies in the field of commercial property leasing, including warehouse areas - it operates in 58 countries (Piekarski, Juściński, 2005; Przegląd rynku..., 2004).

In accordance with the definition presented by the European Association of Logistics Centres "Europlatforms", a logistics centre is a designated area where all the activities relating to transport, logistics and goods distribution both for national and international transit are carried out. Services are provided by various entities on a commercial basis. A logistics centre should (Europlatforms, 2017):

- be open to all interested companies,

- be multimodal, i.e. provide access to several modes of transport and support intermodal transport,

- offer public services to users,

- comply with European quality and performance standards.

In Polish literature, a logistics centre is most often defined as: a spatial object with its own organization and infrastructure which allow independent enterprises to perform actions on goods in relation to their storage and transportation between the sender and the recipient, including support for intermodal transport and providing various services to users (Kisperska, 2009, p. 287).

Table 1. Comparison of selected logistics facilities

\begin{tabular}{|c|c|c|c|c|c|c|c|c|c|c|c|c|c|c|c|c|c|c|c|c|c|c|c|c|}
\hline \multirow[b]{2}{*}{$\begin{array}{l}\text { The type } \\
\text { of object }\end{array}$} & \multicolumn{10}{|c|}{ Infrastructure } & \multicolumn{14}{|c|}{ Scope of services } \\
\hline & 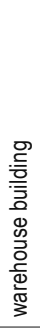 & 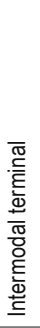 & 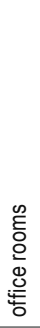 & 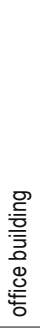 & 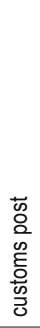 & 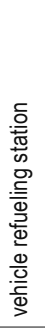 & 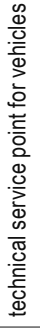 & 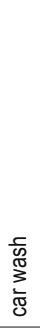 & 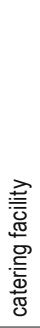 & ब्ञ & $\begin{array}{l}\mathscr{8} \\
\frac{\pi}{0} \\
\frac{0}{\infty}\end{array}$ & 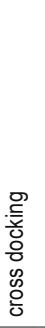 & 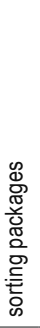 & 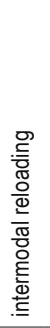 & 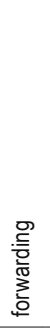 & 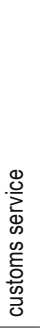 & 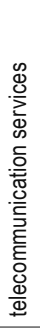 & 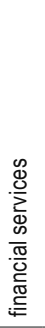 & 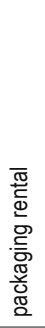 & 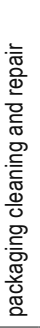 & $\begin{array}{l}\frac{\mathscr{D}}{\mathbb{J}} \\
\frac{\mathscr{D}}{\mathbb{D}} \\
\stackrel{2}{巳}\end{array}$ & 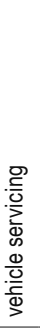 & 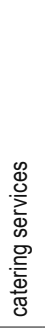 & 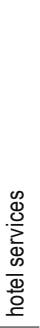 \\
\hline Logistic centre & + & + & + & + & + & + & + & + & + & + & + & + & + & + & + & + & + & + & + & + & + & + & + & + \\
\hline Warehouse centre & + & - & + & - & - & - & - & - & - & - & + & + & + & - & + & + & + & - & - & - & - & - & - & - \\
\hline
\end{tabular}

Source: own elaboration based on Kisperska-Moro, Krzyżaniak (2009).

In addition to logistics centre, there can be distinguished warehouse and distribution or logistics-distribution centres. The main difference between a logistics centre and a warehouse centre is the range of offered services and access to various means of transport. A logistics centre has to have access to at least two modes of transport, and have an intermodal terminal as one of its elements. It also offers a range of services related to the supply chain management process. In most cases, a warehouse centre only includes storage facilities with an office part, and is only serviced by road (Table 1). The difference is already visible at the investment stage. Warehouse centres were built by one investor, most often industrial developers, in accordance with standard projects, whereas logistics centres were created by many entities, often with the participation of local-government. It should be emphasized 
that not all facilities called logistics centres are them in reality. Often the name resulted from the marketing strategy of a given company, e.g. for the determination of a finished goods warehouse or a central warehouse (Fechner, 2004).

\section{Development of warehouse infrastructure in Poland}

Warehouse facilities built by industrial developers were created as a part of Build-to-Suit (BTS) investments their localization, space, as well as technical and performance characteristics were agreed with the lessee before the construction started, or as semi-speculative projects - the infrastructure did not have a predetermined lessee. The number of modern facilities and warehouse complexes in Poland has been dynamically growing in recent years. Modern warehouse areas are facilities put to use after 2000. In 2012-2017, 80 warehouse complexes, and a total of over 3.6 million $\mathrm{m}^{2}$ of warehouse area (Table 2) were built in Poland. In 2018, the total warehouse area in modern warehouse complexes exceeded 15 million $\mathrm{m}^{2}$. The biggest developers in terms of the number of warehouse complexes offered were: Pannattoni - 24 in 2012 and 30 in 2017, and Prologis - 26 in 2012 and 21 in 2017. In the analysed years, this group was joined by: Logicor, Segro and Goodman that at the end of February 2017 managed respectively 19, 14 and 12 warehouse centres. In terms of warehouse area in 2017, Prologis was the largest one with 2,218.9 thousand $\mathrm{m}^{2}$, Logicor -844.6 thousand $\mathrm{m}^{2}$, Segro -757.7 thousand $\mathrm{m}^{2}$, and Panattoni -570.6 thousand $\mathrm{m}^{2}$ (Marketbeat Poland... 2018; own elaboration based on the offer Cushman \& Wakefield 02.2012 and 02.2017).

Tahle 2. Warehouse stock in Polish voivodeships in 2012 and 2017

\begin{tabular}{lcccc}
\hline & \multicolumn{2}{c}{ February 2012} & \multicolumn{2}{c}{ February 2017 } \\
\cline { 2 - 5 } & $\begin{array}{c}\text { Voivodeship } \\
\text { the number of warehouse } \\
\text { centres }\end{array}$ & $\begin{array}{c}\text { warehouse area } \\
\text { (sq. meters) }\end{array}$ & $\begin{array}{c}\text { the number of warehouse } \\
\text { centres }\end{array}$ & $\begin{array}{c}\text { warehouse area } \\
\text { (sq. meters) }\end{array}$ \\
\hline Poland & 105 & $5,910,940$ & 185 & $9,510,457$ \\
\hline Dolnośląskie & 8 & 525,900 & 19 & $1,108,377$ \\
Kujawsko-Pomorskie & 2 & 65,100 & 5 & 165,101 \\
Lubelskie & - & - & 4 & 93,187 \\
Lubuskie & - & - & 1 & 4,700 \\
Lódzkie & 14 & 858,230 & 21 & $1,300,834$ \\
Małopolskie & 6 & 109,780 & 12 & 339,284 \\
Mazowieckie & 40 & $2,143,780$ & 60 & $2,960,968$ \\
Opolskie & - & - & - & - \\
Podkarpackie & 2 & 48,390 & - & 53,229 \\
Podlaskie & - & - & 8 & - \\
Pomorskie & 4 & 137,000 & 30 & 446,336 \\
Śląskie & 19 & $1,209,740$ & - & $1,715,466$ \\
Świętokrzyskie & - & - & - & - \\
Warmińsko-Mazurskie & - & - & 19 & - \\
Wielkopolskie & 9 & 766,360 & 4 & $1,130,132$ \\
Zachodniopomorskie & 1 & 46,660 & 192,843 \\
\hline
\end{tabular}

Source: own elaboration based on the offer Cushman \& Wakefield.

The highest concentrations of warehouse centres were located around large cities: Warszawa, Poznań, Wrocław and Łódź agglomerations, the Katowice and trójmiejska urban areas, as well as Kraków and Szczecin. On the other hand, Opolskie, Świętokrzyskie, Podlaskie and Warmińsko-Mazurskie voivodeships did not have 
warehouse centres (Figure 1). In 2018, the first warehouse centre was opened in Białystok in Podlaskie voivodeship. At that time, the first warehouse complexes were under construction in Świętokrzyskie and Warmińsko-Mazurskie voivodeships (Cushman, Wakefield, 2018).

In addition to the developers, warehouse centres were owned by logistics operators, e.g. Sistema Poland 5 (Tychy, Łódź, Bieruń, Sosnowiec, Bielsko-Biała), Muller die Logistyk - 2 (Gliwice, Wrocław), Ost Sped - 2 (Kalisz and Gaqdki) (Based on information published by the listed companies). Large retail chains had their own warehouse infrastructure. Some of these distribution centres had access to railways - including facilities belonging to: Ikea Hanim Poland SA, Castorama Polska Sp. z 0.0., Jysk Sp. z 0.0. and Blum Polska Sp. z 0.o. (Bocheński, 2014).

Warehouse centres established in Poland were focused on providing services using mainly road transport. Warehouse facilities were often located in the vicinity of road junctions on motorways and expressways, away from railway lines and stations. Only $14 \%$ of them had access to the railway in 2013 - had their own siding. A characteristic feature was that a significant part of the facilities was located near container terminals (Figure 1), which made it possible to use intermodal transport. About $42 \%$ of warehouse complexes were located within a radius of $10 \mathrm{~km}$ from the nearest container terminal (Bocheński, 2014).

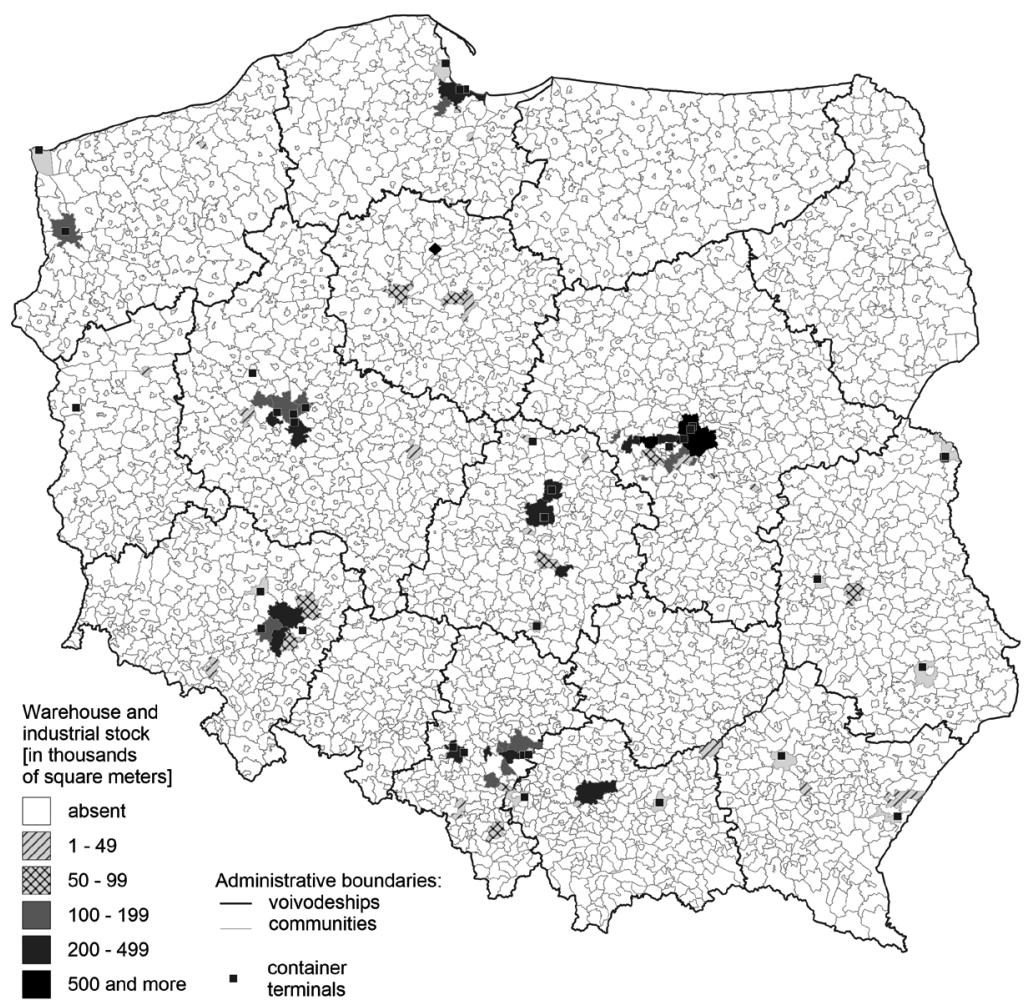

Figure 1. Warehouse and industrial stock in communities and location of container terminals in Poland - February 2017.

Source: own elaboration based on: the offer Cushman \& Wakefield from February 15, 2017; information published by the Silesian Logistics Centre and Wielkopolska Logistics Centre; Bocheński (2018). 


\section{Logistics centrpes in Poland}

There is no network of logistics centres in Poland. Demand for modern warehouses has been met by industrial developers who have built and managed warehouse centres. The existing logistics centres were created as a result of local initiatives. This was due to the lack of national policy in the area of logistics infrastructure development (Fechner, Krzyżaniak, 2013, pp. 97-107). There can be distinguished about 10 potential logistics centres in Poland (Table 3). However, only 2 of them met most of the criteria for logistics centres: Silesian Logistics Centre in Gliwice and CLIP Logistics in Swarzędz.

Table 3. Equipment of potential logistics centres in Poland

\begin{tabular}{|c|c|c|c|c|c|c|c|}
\hline \multirow[b]{2}{*}{ The name of the object } & \multirow[b]{2}{*}{ 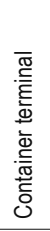 } & \multirow[b]{2}{*}{ 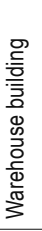 } & \multirow[b]{2}{*}{ 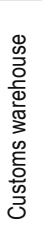 } & \multirow[b]{2}{*}{ 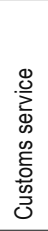 } & \multicolumn{3}{|c|}{ Storage area } \\
\hline & & & & & $\begin{array}{l}\text { storage } \\
\text { yards for } \\
\text { containers } \\
\text { (TEU) }\end{array}$ & $\begin{array}{c}\text { covered } \\
\text { warehouses } \\
\left(\mathrm{m}^{2}\right)\end{array}$ & $\begin{array}{c}\text { other } \\
\text { storage yards } \\
\qquad\left(\mathrm{m}^{2}\right)\end{array}$ \\
\hline Euroterminal Sławków & + & - & + & + & 3,700 & 8,500 & $118,200^{\mathrm{a}}$ \\
\hline Silesian Logistics Centre in Gliwice & + & + & + & + & 2,850 & 28,000 & 25,000 \\
\hline CLIP Logistics in Swarzędz & + & - & + & + & 4,500 & 300,000 & - \\
\hline Wielkopolska Logistics Centre Konin-Stare Miasto & - & + & + & + & - & 13,000 & - \\
\hline Pomerania Logistics Centre (Goodman) & $+{ }^{b}$ & + & - & + & $55,000^{\mathrm{b}}$ & $500,000^{c}$ & - \\
\hline West Pomerania Logistics Centre in Szczecin seaport & $+t^{d}$ & - & $+e$ & nd & $4,000^{d}$ & $56,000^{\mathrm{e}}$ & $140,000^{\mathrm{e}}$ \\
\hline Logistics Centre of Gdynia seaport & $+f$ & + & + & - & $\sim 30,000^{f}$ & 31,840 & - \\
\hline Logistics Centre PKP Cargo in Małaszewicze & + & - & +9 & + & $\begin{array}{c}1,872 \\
>3,200^{9}\end{array}$ & nd & 45,000 \\
\hline Logistics Centre PKP Cargo in Medyka-Żurawica & + & - & - & + & 80 & nd & 7,596 \\
\hline Logistics Centre in Łosośna & - & - & - & + & - & 1,137 & 50,000 \\
\hline
\end{tabular}

nd - no data.

${ }^{\mathrm{a}}$ - including steel product $\left(8,200 \mathrm{~m}^{2}\right)$ and bulk cargo $\left(110,000 \mathrm{~m}^{2}\right) ;{ }^{b}-$ maritime container terminal DCT; ${ }^{\mathrm{C}}-$ target area; ${ }^{\mathrm{d}}-$ maritime container terminal of DB Port SzCzecin; ${ }^{\mathrm{e}}-$ Free Customs Area on the general cargo terminal of DB Port Szczecin; ${ }^{\dagger}$ - maritime container terminals BCT and GCT; ${ }^{9}$ - including terminals Europort and Adampol.

Source: own elaboration based on information published by managers of logistic centres and seaports.

The initiatives to create logistics centres were undertaken in, among others, the hinterland of the main ports in Gdańsk, Gdynia, Szczecin and in dry ports at the interface between normal and wide tracks in: Sławków, near Przemyśl and Małaszewicze. In 2007, Zachodniopomorskie Centrum Logistyczne was created next to DB Port Szczecin container terminal. So far, only truck parking lots have been constructed on it site, and the majority of the area remains undeveloped. In Gdańsk, in the vicinity of the DCT terminal, a warehouse centre was built by the developer Goodman (Bocheński, Palmowski, 2015). Whereas in Gdynia, the concept of creating the so-called Logistic Valley, stretching west of the port of Gdynia was developed. The Gdynia Port Authority directly invested in the construction of warehouses for rent (Gdynia Maritime Port Authority SA, 2017). The potential logistics centre was Euroterminal Sławków located within the Katowice urban area at the end of the Broad-Gauge Metallurgical Railway Line. A similar function was performed by PKP Cargo facilities in the Medyka-Żurawica reloading area near Przemyśl and Małaszewicze. There were reloading unit assemblies belonging to different operators, located at the 
junction of broad-gauge $(1,520 \mathrm{~mm})$ and European standard-gauge $(1,435 \mathrm{~mm})$ railway lines (Bocheński, 2017; Bocheński, 2018).

In 2015, 6 Polish centres belonged to the European Association of Logistics Centres "Europlatforms": Pomeranian Logistics Centre in Gdańsk, the Port of Gdynia's Logistics Centre, Zachodniopomorskie Logistics Centre in Szczecin, Euroterminal Sławków, Silesian Logistics Centre in Gliwice and CLIP in Swarzędz.

The problem of existing logistics infrastructure facilities in Poland was primarily the lack of access to at least two modes of transport and insufficient scope of additional services. Multimodality is one of the most important elements of a logistics centre, one of whose tasks is to support intermodal transport.

\section{Conclusions}

At the current stage of the development of the logistics market in Poland, the creation of a network of logistics centres similar to other European countries seems unlikely. This is due to the omission of this issue in the state's transport policy. The demand for modern warehouse areas is met by dynamically developing warehouse centres built by developers. In 2018, there were about 200 warehouse centres in Poland with a total warehouse area of over 15 million $\mathrm{m}^{2}$. The biggest industrial developers that offered warehouse area to let in 2017 were Prologis, Logicor, Segro and Panattoni. Among the potential logistics centres, only 2 met most of the criteria for logistics centres: Silesian Logistics Centre in Gliwice and CLIP Logistics in Swarzędz.

The examined logistics infrastructure was concentrated in the largest agglomerations: Warszawa, Łódź, Wrocław, Poznań and the trójmiejska and Katowice urban areas. Opolskie voivodeship did not have any of this type of infrastructure, whereas in Podlaskie, Świętokrzyskie and Warmińsko-mazurskie voivodeships, the first facilities of this type had not been created until 2018. A majority of the facilities were operated by car transport alone. The lack of fully developed logistics centres and the focus of most warehouse centres on providing services only by road transport hampered the development of intermodal rail transport.

\section{References}

Bocheński, T. (2018). Rozmieszczenie i charakterystyka terminali kontenerowych w Polsce oraz propozycje lokalizacji nowych obiektów. Problemy Transportu i Logistyki, 41, 17-27.

Bocheński, T. (2014). Rola kolei w obsłudze centrów logistycznych i transportu intermodalnego w Polsce. Problemy Transportu i Logistyki, 28, 21-35.

Bocheński, T. (2017). Funkcjonowanie rejonów przeładunkowych na styku sieci kolejowych o rozstawie torów 1435 i $1520 \mathrm{~mm}$ w Europie. Prace Komisji Geografii Przemysłu Polskiego Towarzystwa Geograficznego, 31 (3), 80-94. https://doi.org/10.24917/ 20801653.313.6.

Bocheński, T., Palmowski, T. (2015). Polskie porty morskie i rola kolei w ich obsłudze na przełomie XX i XXI wieku. Regiony Nadmorskie 23. Gdańsk-Pelplin: Wydawnictwo Bernardinum.

Cushman \& Wakefield (2017). Retrieved from: www.industrial.pl.

Europlatforms (2017). Retrieved from: www.europlatforms.eu/definition.

Fechner, I. (2004). Centra logistyczne. Cel, realizacja, przyszłość. Poznań: Logistics and Warehousing Institute.

Fechner, l., Krzyżaniak, S. (2013). Rola i znaczenie centrów logistycznych w rozwoju transportu intermodalnego w Polsce. Problemy Transportu i Logistyki, 22, 97-107.

Kisperska-Moro, D., Krzyżaniak, S. (2009). Logistyka. Poznań: Logistics and Warehousing Institute.

Marketbeat Poland warehouse market Q3 2018 (2018). Cushman \& Wakefield. Retrieved from: www.cushmanwakefield.pl/en-gb/ research-and-insight/2018/rynek-powierzchni-przemyslowych-i-logistycznych-w-iii-kwartale-2018-r. 
Piekarski, W., Juściński, S. (2005). Centra logistyczne w Polsce po wejściu do Unii Europejskiej. Eksploatacja i Niezawodność Maintenance and Reliability, 4, 46-54.

Przegląd rynku powierzchni magazynowo-logistycznych w Polsce - raport (2004). Warszawa: CB Richard Ellis Limited.

Zarząd Morskiego Portu Gdynia SA (2017). Retrieved from: www.port.gdynia.pl.

Cite this article aS: Bocheński, T. (2018). Warehouse and logistics centres in Poland. European Journal of Service Management, 4 (28/2), 73-79. DOI: 10.18276/ejsm.2018.28/2-08. 